\title{
Geochemical properties and agricultural suitability of groundwater at landfill site, Baghdad, Iraq
}

\author{
Raghad Salman Mouhamad ${ }^{1 *}$, Samia Khalel ${ }^{3}$, Muna Q. Ali ${ }^{1}$, Saad Obaid Joda ${ }^{2}$, Arif Nazir ${ }^{4}$, \\ Munawar Iqbal ${ }^{4}$ and Nadia Salman Nasif ${ }^{2}$
}

\author{
${ }^{1}$ Soil and Water Center, Ministry of Sciences and Technology, Baghdad, Iraq. \\ ${ }^{2}$ Department of Geography, College of Education, University of Al-Mustansiriyah, Baghdad, Iraq. \\ ${ }^{3}$ Department of Biotechnology, College of Science, Nahrain University, Baghdad, Iraq. \\ ${ }^{4}$ Deprtment of Chemistry, The University of Lahore, Lahore, Pakistan.
}

Accepted 1 December, 2017

\begin{abstract}
Contamination of groundwater is considered as one of the major environmental problems. The groundwater resources are being utilized for drinking, irrigation and industrial purposes. There is growing concern on deterioration of groundwater quality due to geogenic and anthropogenic activities. This research aims to study the quality assessment through the estimation of $\mathrm{Ca}^{2+}, \mathrm{Mg}^{2+}, \mathrm{Na}^{+}, \mathrm{K}^{+}, \mathrm{CO}_{3}{ }^{2-}, \mathrm{HCO}_{3}{ }^{-}, \mathrm{Cl}^{-}, \mathrm{SO}_{4}{ }^{2-}, \mathrm{EC}$, TDS and $\mathrm{pH}$ in the Landfill site of Baghdad city based on the analyses, parameters such as sodium adsorption ratio (SAR), sodium percentage, residual sodium carbonate (RSC), permeability index (PI), Gibbs Ratio I (for anion), Gibbs Ratio II (for cation), Chloroalkali indices (CAL 1 and CAL 2) for anion and cation were calculated. Analytical results of groundwater samples show that they are severely polluted and incidentally found, estuaries and salt pans in the study area. The Gibbs plot indicates that the majority of groundwater samples fall in the evaporation dominant region, which indicates wastewater leaching interaction in the study area. This might be attributed to the type of wastes interactions, ion-exchange reactions and runoff of fertilizers from the surrounding agricultural lands on landfill site.
\end{abstract}

Keywords: Groundwater quality, geochemical analysis, agriculture, leaching, Iraq.

*Corresponding author. E-mail: raghad1974@yahoo.com.

\section{INTRODUCTION}

Baghdad is the largest and most heavily populated city in Iraq with an area of Baghdad Governorate reaches 5159 $\mathrm{km}^{2}$. The estimated population is 7 million (Nussaif and Qamar, 2007).

The rapid growth of population, increasing municipal, industrial and agricultural activities as well as the natural and man-induced climatic changes have led to significant changes in water resources (surface and groundwater) quality demands as well as the properties of soil. These factors have resulted in significant changes in the environment and then potential risk on the human life can occur.

Al-Hiti (1985) carried out detailed study on groundwater quality within Baghdad city. Groundwater flow directions and water quality evaluation was also determined. He found that the concentrations of the trace elements were within the permissible limits for drinking water. While Abdul-Karim (1996) detected the effect of Al-Rasafa landfill site on groundwater quality, and explained that the concentrations of the ions within the leachate increase with time for an active landfill.

Al-Hassany (2003) studied the environmental characteristic of groundwater within Al-Dora area, indicating that the flow direction is towards Tigris River. Hydro-chemical evaluation of the groundwater aquifer at many locations was also achieved. Also Abdul-Hussain (2007) explored the hydro-chemical and environmental aspects of the infiltrated water of Baghdad area, showing that these waters were very hard and brackish and were of sulfate type.

The study by Sausan (2012) explored the hydrochemical parameters of the groundwater explain 
significant spatial and temporal variations in major and minor elements, whereas the parameters of the Tigris River show significant differences at high and low flow conditions, and there is clear difference from station to another due to the geological and hydrological factors as well as the human activities. Nadia (2014) investigated the AL-Emary, AL-Boaatha, Erkaia and Fathel areas, and its impact on these endless supply of soil, the outcomes of the concoction examination of substantial components $\mathrm{Cu}, \mathrm{Pb}, \mathrm{Cd}, \mathrm{Ni}$ and $\mathrm{Zn}$. The three covered areas are contaminated by those components, exceptionally Erkaia and Fathel where higher fixation were recorded. Yousir (2016) investigated three WWTP pumping stations releasing water into the Diyala River, while the dirt flooded with river water and plant developed in the same soil demonstrated higher $\mathrm{Zn}, \mathrm{Co}, \mathrm{Cu}, \mathrm{Mn}, \mathrm{Fe}, \mathrm{Cr}, \mathrm{Cd}, \mathrm{Ni}$ and $\mathrm{Zn}$ focus, water quality is altered because of blending of city and modern wastewater into Diyala river. Mouhamad (2017) last investigation from three sites of landfill, located in south Baghdad city, Iraq and were most water samples from the studied area were contaminated and this in-turn have social and environmental impact.

The locations of garbage burial have made big damages to the surrounding eco-system in the atmosphere, on the earth surface or in the soil (Kannan and Sabu, 2010). So the wasted material in these locations interacts in the nature and decay by many factors under different conditions of temperature, rainfall, humidity, and winds. This fosters as well as biological factor help the decay process and filtering crosses the soil to reach the groundwater. The use of such water absolutely causes risk to health, economy, society, and environment.

This study presents soil and groundwater characteristics in Baghdad city for Al-Emary, Al-Boaatha, Erkaia and Fathel locations.

\section{MATERIALS AND METHODS}

\section{Selection of wells and collection of water samples}

The groundwater samples were collected from 3 locations from Baghdad landfill sites on June 2013 and water samples were transported to the laboratory of Geology Department, Iraqi Geological survey.

\section{Analytical procedure}

Different procedures were used to analyze the collected samples for parameters such as $\mathrm{Na}^{+}, \mathrm{K}^{+}, \mathrm{Mg}^{2+}, \mathrm{Ca}^{2+}, \mathrm{Cl}^{-}, \mathrm{SO}_{4}^{-}, \mathrm{HCO}_{3}^{-}$, \& $\mathrm{CO}_{3}^{-}$, that are the major ions in groundwater of landfill. Calcium and Magnesium content were determined by EDTA titration using Eriochrome black $\mathrm{T}$ as indicator. Sodium and potassium content were determined by using a flame photometer. Chloride concentration was measured by silver nitrate titration. Carbonate and bicarbonate content were measured by acid-base titration. Sulphates content was measured by using colorimetricspectrophotometer. Conductivity meter was used to measure the
Electrical Conductivity. The accuracy of the analysis for major ions was cross checked from the electrical balance (E.B), since the sum of positive and negative charges in the water should be equal.

The samples were subjected to different analysis for $\mathrm{pH}$, conductivity, Na\%, SAR, RSC, Gibbs ratio I (for anion), Gibbs ratio II (for cation), chloroalkali indices (for anion) and (for cation) and PI $\%$.

To determine the irrigation suitability of water, sodium adsorption ratio (SAR) (Richards, 1954), residual sodium carbonate (RSC) (Eaton, 1950), sodium percentage ( $\mathrm{Na} \%$ ) (Wilcox, 1955) and permeability index (PI) (Doneen, 1966) were calculated using the following formulae (ions concentrations expressed as milli equivalents/litre). The salinity hazard was calculated based on electrical conductivity value at $25^{\circ} \mathrm{C}$ expressed as mmohs $/ \mathrm{cm}$.

$$
\begin{aligned}
& \mathrm{RSC}=\left[\mathrm{CO}_{3}{ }^{2-}+\mathrm{HCO}_{3}{ }^{-}\right]-\left[\mathrm{Ca}^{2+}+\mathrm{Mg}^{2+}\right] \\
& \mathrm{SAR}=\mathrm{Na} /\{(\mathrm{Ca}+\mathrm{Mg}) / 2\} 1 / 2 \\
& \% \mathrm{Na}=(\mathrm{Na}+\mathrm{K}) 100 /(\mathrm{Ca}+\mathrm{Mg}+\mathrm{Na}+\mathrm{K}) \\
& \mathrm{PI}=\mathrm{Na}+\left(\mathrm{HCO}_{3}\right) 1 / 2 /(\mathrm{Ca}+\mathrm{Mg}+\mathrm{Na}+\mathrm{K}) \\
& \text { Gibbs Ratio I (for anion) }=\mathrm{Cl}^{-} /\left(\mathrm{Cl}^{-}+\mathrm{HCO}_{3}{ }^{-}\right) \\
& \text {Gibbs Ratio II (for cation) }=\mathrm{Na}^{+}+\mathrm{K}^{+} /\left(\mathrm{Na}^{+}+\mathrm{K}^{+}+\mathrm{Ca}^{2+}\right) \\
& \text { Chloro Alkaline Indices } 1=[\mathrm{Cl}-(\mathrm{Na}+\mathrm{K})] / \mathrm{Cl}^{2+}
\end{aligned}
$$

Chloro Alkaline Indices $2=[\mathrm{Cl}-(\mathrm{Na}+\mathrm{K})] /\left(\mathrm{SO}_{4}+\mathrm{HCO}_{3}+\mathrm{CO}_{3}+\right.$ $\mathrm{NO}_{3}$ )

The samples concentrations of ionic constituents of all elements are calculated in $\mathrm{mg} / \mathrm{dl}$.

\section{RESULTS AND DISCUSSION}

\section{Site portrayal}

Three locales of landfill, situated in south Baghdad city, Iraq, were incorporated into this investigation amid the period from first March 2013 till first March 2014. The locales were specifically, Al-Emarry, Al-Boaatha, Erkaia and Fathel as shown in Figure 1.

Atomic absorpatio spectrophotometer was utilized for quantitation examination of substantial metals consumed by groundwater. The grouping of $\mathrm{Cd}$ amassed in $\mathrm{Al}$ Emary and Erkaia and Fadhel locales expanded achieved Mean stander blunder (MSE) $236 \pm 41.01$ and $242.5 \pm 44.55$ contrasted and Al Boaatha site achieved $194 \pm 40.31$ of Cd focus (Table 1). This is in concurrence with Nadia (2014) who grouped Cd as a component of middle danger. Al Emary the convergences of substantial metals expanding achieving $0.045 \pm 0.007$ and $0.87 \pm$ 0.32 MSE of $\mathrm{Cu}$ and Fe individually. In Erkia and Fadhel and Al Boaatha destinations, this sum started to diminished in MSE $(0.125 \pm 0.049$ and $0.0352 \pm 0.004)$ of $\mathrm{Cu}$ fixations individually (Table 1). This outcome is in concurrence with Nadia (2014) who found that $\mathrm{Co}, \mathrm{Cu}$, $\mathrm{Cr}, \mathrm{Zn}$, and Nil are poisonous components to groundwater at high levels. Fe fixation declined in Erkaia and Fadhel contrasted and Al Boaatha. 


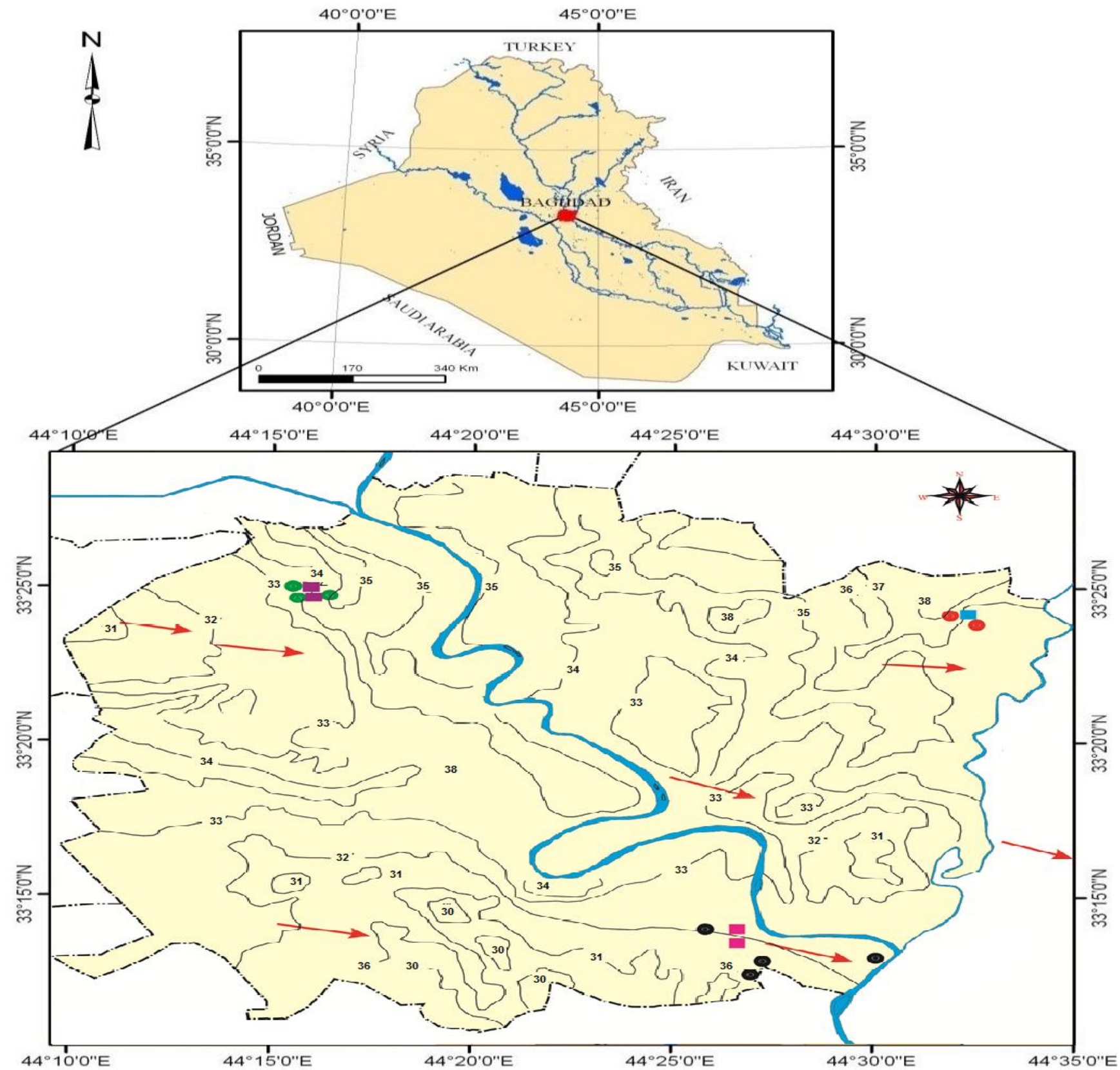

1.5 $4.5 \mathrm{~km}$

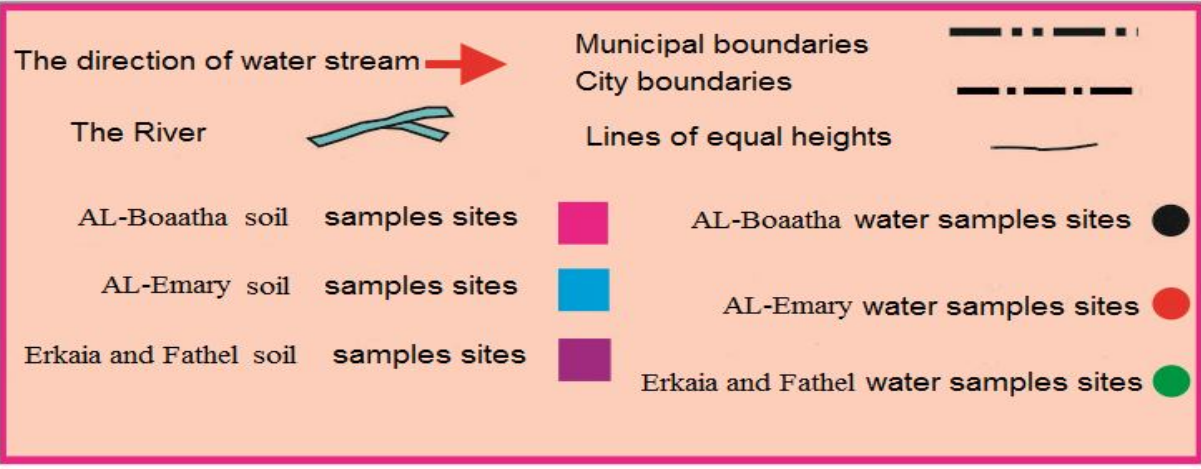

Figure 1. Location map of study area. 
Table 1. MSE represents the results of various analyses.

\begin{tabular}{|c|c|c|c|c|c|c|c|c|c|c|c|c|c|c|}
\hline $\begin{array}{l}\text { Location } \\
\text { name }\end{array}$ & GPS & $\begin{array}{c}\text { T.H as } \mathrm{CaCO}_{3} \\
\text { (mg/dl) }\end{array}$ & $\mathrm{SO}_{4}(\mathrm{mg} / \mathrm{dl})$ & $\mathrm{Na}(\mathrm{mg} / \mathrm{dl})$ & $\begin{array}{c}\mathrm{Mg} \\
(\mathrm{mg} / \mathrm{dl})\end{array}$ & $\mathrm{Ca}(\mathrm{mg} / \mathrm{dl})$ & $\mathrm{Zn}(\mathrm{mg} / \mathrm{dl})$ & $\begin{array}{c}\mathrm{K} \\
(\mathrm{mg} / \mathrm{dl}) \\
\end{array}$ & $\mathrm{NO}_{3}$ (mg/dl) & $\begin{array}{l}\mathrm{HCO}_{3} \\
(\mathrm{mg} / \mathrm{dl})\end{array}$ & $\mathrm{Cd}(\mathrm{mg} / \mathrm{dl})$ & $\mathrm{CO}_{3} \mathrm{mg} / \mathrm{dl}$ & $\begin{array}{c}\mathrm{Fe} \\
(\mathrm{mg} / \mathrm{dl})\end{array}$ & $\begin{array}{c}\mathrm{Cu} \\
(\mathrm{mg} / \mathrm{dl})\end{array}$ \\
\hline Al-Emary & 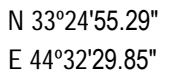 & $2656 \pm 550^{A}$ & $1513 \pm 882^{A}$ & $1775 \pm 106.1^{\mathrm{A}}$ & $955 \pm 197^{A}$ & $275 \pm 58^{A}$ & $617.8 \pm 332^{A}$ & $\begin{array}{c}0.7997 \\
\pm 0.252^{A}\end{array}$ & $6.8 \pm 1.6^{\mathrm{A}}$ & $26.67 \pm 9.57^{A}$ & $236 \pm 41.01^{\mathrm{A}}$ & $\begin{array}{c}0.0275 \\
\pm 0.00071 \mathrm{~A}\end{array}$ & $\begin{array}{c}0.87 \\
\pm 0.3269 \mathrm{~A}\end{array}$ & $\begin{array}{c}0.0455 \\
\pm 0.00734^{\mathrm{A}}\end{array}$ \\
\hline Al-Boaatha & $\begin{array}{l}\text { N } 36^{\circ} 74^{\prime} 40.68^{\prime \prime} \\
\text { E } 44^{\circ} 81^{\prime} 52^{\prime \prime}\end{array}$ & $3788 \pm 905^{в}$ & $6765 \pm 916^{B}$ & $1460 \pm 198^{B}$ & $6489 \pm 267 \mathrm{~B}$ & $1583 \pm 716^{B}$ & $936 \pm 165^{A}$ & $\begin{array}{c}0.0348 \\
\pm 0.001^{B}\end{array}$ & $289.3 \pm 92.1^{B}$ & $55.83 \pm 11.98^{8}$ & $194 \pm 40.31^{A}$ & $\begin{array}{c}0.05375 \\
\pm 0.00823 \text { в }\end{array}$ & $\begin{array}{c}0.2575 \\
\pm 0.0688 \text { в }\end{array}$ & $\begin{array}{c}0.03525 \\
\pm 0.00457 \mathrm{~A}\end{array}$ \\
\hline $\begin{array}{l}\text { Erkaia and } \\
\text { Fadhel }\end{array}$ & 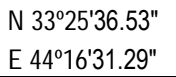 & $2730 \pm 603^{A}$ & $4826 \pm 275^{c}$ & $1840 \pm 226.3^{A}$ & $1999 \pm 225^{c}$ & $402 \pm 14^{c}$ & $447 \pm 127.8^{A}$ & $\begin{array}{c}0.059 \\
\pm 0.0036 \mathrm{~B}\end{array}$ & $136 \pm 75.4 \mathrm{C}$ & $21.3 \pm 7.5^{\mathrm{A}}$ & $242.5 \pm 44.55^{\mathrm{A}}$ & $\begin{array}{c}0.0295 \\
\pm 0.00344 \mathrm{~A}\end{array}$ & $\begin{array}{c}0.1495 \\
\pm 0.0153 \mathrm{c}\end{array}$ & $\begin{array}{c}0.1255 \\
\pm 0.0492^{\mathrm{B}}\end{array}$ \\
\hline
\end{tabular}

Differences letters $A, B$ are significant at $(P<0.05)$ to compression columns.

\section{pH}

All the tested groundwater samples fell in the $\mathrm{pH}$ range of 6.5 to 8.4 , which are within the normal range for irrigation limit except for Al-Emary which was a $\mathrm{pH}$ above the permissible limit (Ramesh and Elango, 2012).

\section{Salinity}

Electrical conductivity (EC) is a good indicator of the salinity hazard to crops as it reflects the TDS concentration in water. EC values lie in the range of 7000 to $34000 \mu \mathrm{mohs} / \mathrm{cm}$, the normal range of EC must be under $3000 \mu \mathrm{mohs} / \mathrm{cm}$, and thus all water samples were above the permissible limit and maybe are toxic to most plants and pose a salinity hazard (Ramkumar et al., 2012).

\section{Sodium adsorption ratio}

Sodium adsorption ratio (SAR) is an important parameter for determining the suitability of groundwater for irrigation because it is a measure of alkali/sodium hazard to crops. The classification of samples based on United States salinity diagram (USRSL, 1954; USGS, 2000), shows the Al-boatha sample water was found unsuitable under water class in USSL.

\section{Residual sodium carbonate}

Residual sodium carbonate (RSC) is another parameter used to classify groundwater for irrigation purposes, the RSC in groundwater is mainly due to the water having higher concentration of bicarbonates ions, which precipitates $\mathrm{Ca}^{2+}$ and $\mathrm{Mg}^{2+}$ ions as their carbonates and increases the $\mathrm{Na}^{+}$ions which increases the sodium carbonate in the groundwater (Srinivas et al., 2014). RSC $<1.25$ in all water samples according to the Richards (1954) classification, so all water samples are within the good class.

\section{Sodium percentage ( $\mathrm{Na} \%)$}

Classifying the groundwater for irrigation based on sodium content is important (Wilcox, 1955). The sodium water reacts with the soils and reduces its permeability which in turn affects the irrigation (Srinivas et al., 2014). The $\mathrm{Na}^{+}$content in groundwater can be expressed in terms of percent sodium ( $\mathrm{Na} \%)$. The concentration of $\mathrm{Na}$ for water sample ranges from 24.92 to $73.69 \%$, that is, more than half of water samples are permeable under Wilcox limit. Groundwater samples with high $\mathrm{EC}$ and $\mathrm{Ca}^{2+}$ and $\mathrm{Mg}^{2+}$ ions replaces $\mathrm{Na}^{+}$ion when absorbed by the clay particles. So this property makes water unfit for irrigation (Zhu et al., 2010).

\section{Permeability index (PI)}

High sodium in the irrigation water can cause severe problems to soil permeability. Permeability is affected not only by high sodium but also by $\mathrm{CO}_{3}{ }^{2-}$ and $\mathrm{HCO}_{3}{ }^{3-}$ which is precipitated as $\mathrm{CaCO}_{3}$ or $\mathrm{MgCO}_{3}$ removing $\mathrm{Ca}$ and $\mathrm{Mg}$ from irrigation water and leads to increased proportion of sodium. The PI of the water samples recorded variations from 20 to $27 \%$. The classification of groundwater was based on the PI by Doneen (1966). 70\% PI for water samples were permissible under Doneen classified while $30 \% \mathrm{PI}$ of sample exceeded $65 \%$ and is considered 
Table 2. Physico-chemical characteristics and Irrigation suitability of groundwater in study area.

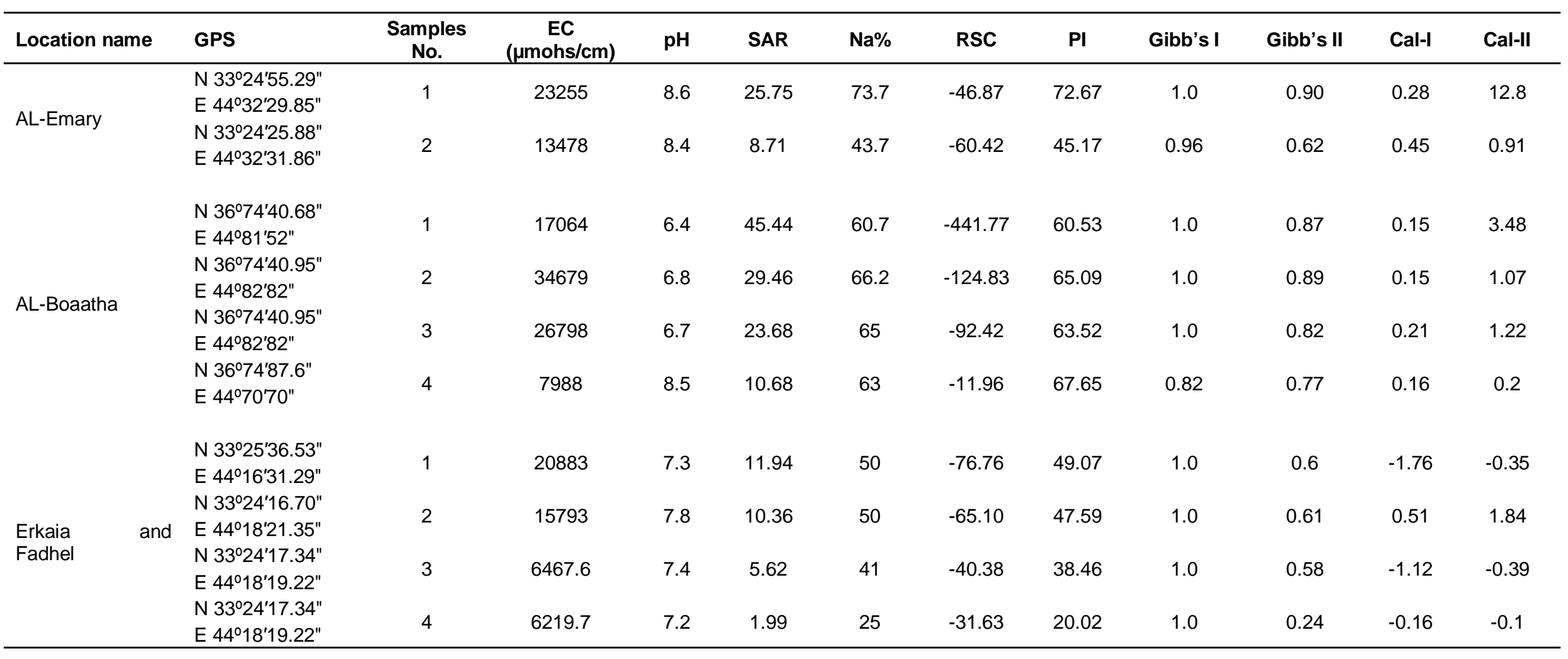

unsuitable for irrigation (Todd, 1980).

\section{lon exchange}

The concentration of ions in groundwater varies when there is an exchange with the ions of it aquifer environment during the periods of residence and movement (Latha and Rao, 2012). Both the indices, CAL 1 and CAL 2 are negative in more than $10 \%$ from water samples and thus there is an exchange of calcium or magnesium in the groundwater with sodium and potassium in the aquifer material. Also the obtained results show that $90 \%$ CAL 1 and CAL 2 of water samples were positive which means reverse ion exchange (Schoeller, 1965).

\section{Gibb's I and Gibb's II}

Indicates that more than $90 \%$ of the groundwater samples are in evaporation dominance, because our study area has higher rate of evapotranspiration characterized by tropical limited and restricted fresh water exchange salt layers may form near the evaporating surface (Gibbs, 1970). The results of Gibbs ratios are given in Table 2.

\section{Groundwater movement and hydraulic gradient of groundwater}

Groundwater movement and lines rise in three landfills (Al-Emary, Al-Boaatha, Erkaia and 
Fathel), that the site Erkaia and Fathel has advantage of being a high line less than or equal to two notches from the Tigris River as the groundwater movement was towards the east and southeast (Hussain and Hussain, 2011).

As Figure 1 showed, the site- Al-Emary is three highest grades (contour lines) from the Tigris River and the direction of movement of groundwater is east and southeast towards the Tigris River, which does not constitute a negative impact on the river and groundwater feeding the Tigris River.

With the movement of groundwater towards east and south-east which is near the site of the landfill, and the river is only $2 \mathrm{~km}$ from the site can be considered the most dangerous sites that pose a serious environmental threat to groundwater and surface water of the Tigris River and the surrounding areas (Abdullah, 2010).

\section{Conclusion}

The salt contents, high temperatures, lack of rain and the varying rates of evaporation has led to the generation of vertical movement of groundwater from the bottom to the surface. This further stimulates the direction of movement of water toward the east and south-east lead to the Tigris River, climate change impacts on water availability, crop yield, crop water productivity and food security. Topography and recharging of water from Tigirs River play vital role for the flow direction of groundwater. The most important irrigation parameters are controlling the groundwater in the study area and their stresses on crops health.

\section{REFERENCES}

Abdul-Hussain FM, 2007. Hydro chemical and environmental study of the infiltrated water in Baghdad City. Ph.D. thesis, College of Science, University of Baghdad, 128p (in Arabic).

Abdul-Karim J, 1996. The effects of Al-Rusafa landfill on local surface and groundwater quality. M.Sc. thesis, College of Engineering, University of Baghdad, $69 \mathrm{p}$.

Abdullah EJ, 2010. Environmental factors affecting diabetic patients in Baghdad City, a specific study in medical geochemistry. Ph.D. thesis, College of Science, University of Baghdad, $195 \mathrm{p}$.

Al-Hiti BM, 1985. Groundwater quality within Baghdad area. M.Sc. thesis, College of Science, University of Baghdad, $235 \mathrm{p}$ (in Arabic).

Doneen LD, 1966. Water quality for Agriculture. Department of Irrigation, University of Calfornia, Davis, $48 \mathrm{pp}$.

Gibbs RJ, 1970. Mechanisms controlling world's water chemistry. Science, 170: 1088-1099.

Hussain S, Hussain SY, 2011. Study of hydrochemical parameters of groundwater around ethanol plant, Bellur.(v.) TQ. Dharmabad dist., Nanded, Maharshtra. Arch Appl Sci Res, 3(2): 606-609.

Kannan N, Sabu J, 2010. Quality of groundwater in the shallow aquifers of a paddy dominated agricultural river basin, Kerala, India. Int J Civil Environ Eng, 2: 160-178.

Latha S, Rao N, 2012. An integrated approach to assess the quality of groundwater in a coastal aquifer of Andhra Pradesh, India. Carpathian J Earth Environ Sci, 66: 2143-2169.
Mouhamad RS, Hussein AA, Alsaedi SA, Nasif NS, Joda SO, 2017. Detect of human fecal contamination in water and soil of multiple sanitary landfills in Baghdad city. Microbiol Res Int, 5(4): 43-50.

Nadia SN, 2014. Change the natural; properties of the soil and groundwater at landfills in the city of Baghdad. M.Sc. thesis, College of Education (Natural Geography), Al Mustansiriyah University, Baghdad, Iraq (in Arabic).

Ramesh K, Elango L, 2012. Groundwater quality and its suitability for domestic and agricultural use in Tondiar River Basin, Tamil Nadu, India. Environ Monit Assess, 184: 3887-3899.

Ramkumar T, Venkatramanan S, Anithamary I, Ibrahim SMS, 2012. Evaluation of hydrogeochemical parameters and quality assessment of the groundwater in Kottur blocks, Tiruvarur district, Tamilnadu, India. Arab J Geosci, 6: 101-108.

Richards LA, 1954. Diagnosis and Improvement of Saline and Alkali Soils. U.S. Department of Agriculture Handbook 60, Washington. pp. 160.

Sausan MA, 2012. Hydrochemical environmental assessment of Baghdad area. Ph.D. thesis, College of Science, University of Baghdad, (in English).

Schoeller H, 1965. Qualitative evaluation of groundwater resources. In Methods and Techniques of Groundwater Investigations and Development. UNESCO, Paris. pp. 54-83.

Srinivas Y, Hudson OD, Stanley RA, and Chandrasekar N, 2014. Quality assessment and hydrogeochemical characteristics of groundwater in Agastheeswaram taluk, Kanyakumari district, Tamil Nadu, India. Chin J Geochem, 33: 221-235.

Todd DK, 1980. Groundwater Hydrology. 2nd edition. Wiley, New York.

USGS (US Geological Survey), 2000. Classification of Natural Ponds and Lakes. Department of the Interior, Washington DC.

USRSL (US Regional Salinity Laboratory), 1954. Diagnosis and Improvement of Saline and Alkali Soils [Z]. pp.1-160.

Wilcox LV, 1955. Classification and Use of Irrigation waters. USDA, Circular 969, Washington DC, USA.

Yousir SA, Mouhamad RS, Fadhel AS, Iqbal M, 2016. Monitoring of Diyala River, Iraq: A comparative study of river, soil and plant receiving treated water from Al-Rustamiya wastewater treatment plant. Phys Chem, 18(1).

Zhu G, Yonghong S, Chunlin H, Feng Q, Zhiguang L, 2010. Hydrogeochemical processes in the groundwater environment of Heihe River Basin, Northwest China. J Environ Earth Sci, 60: 139153.

Citation: M ouhamad RS, Khalel S, Ali MQ, Joda SO, Nazir A, Iqbal M, Nasif NS, 2017. Geochemical properties and agricultural suitability of groundwater at landfill site, Baghdad, Iraq. Int J Ecol Ecosolution, $4(2): 17-22$. 